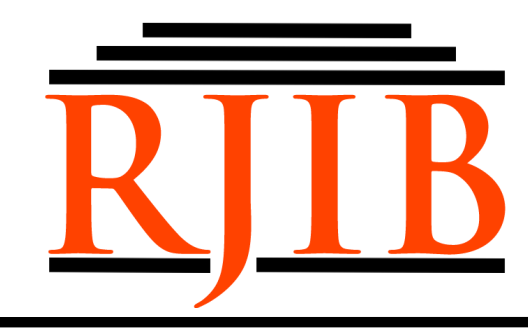

RETORIKA: Jurnal Ilmu Bahasa

Vol. 5, No. 1 April 2019, Page 7-11

\title{
Speech Acts and Principles of Daily in Dental Post Advertisements on Youtube Period (2015-2018)
}

Ni Putu Andini Desiyanti Laksmi
$\begin{aligned} & \text { Universitas Warmadewa, Denpasar,Bali-Indonesia } \\
& \text { angel0n3arth@yahoo.co.id }\end{aligned}$
\begin{tabular}{|l|c|}
\hline Received: $16 / 08 / 2018$ & Revised: 07/01/2019 \\
\hline $\begin{array}{l}\text { How to cite (in APA style): } \\
\text { Laksmi, N, P, A, D. (2019). Speech Acts and Principles of Daily in Dental Post Advertisements on Youtube Period (2015- } \\
\text { 2018). RETORIKA: Jurnal Ilmu Bahasa, 5(1), 7-11. doi: http://dx.doi.org/10.22225/jr.5.1.758.7-11 }\end{array}$ \\
\hline
\end{tabular}

\begin{abstract}
Every utterance that is uttered has a certain purpose and meaning. Thus, an effort is needed to interpret the utterance which is called speech acts. The aims of this research is to explain (1) types of speech acts (2) categories of illocutionary acts, and (3) politeness principles contained in the utterance on toothpaste advertisements on youtube period (2015-2018). The data in this research were taken from toothpaste advertisements that have been shown on television channels. The data collected are in the form of image footage and utterances contained in the advertisement. The results of the analysis show that (1) there is a difference between locution and illocutionary acts in adult's and children's toothpaste advertisements, namely that adult toothpaste advertisements highlight information about the advantages of toothpaste, while the children's toothpaste advertisement emphasizes information about nonverbal advertising, (2) illocutionary acts in the advertisement indicated that there were 6 assertive utterances, 9 directive utterances, 6 commissive utterances, 6 expressive utterances, and 2 declarative utterances, (3) the politeness principles found in those advertisements are 15 tact maxims, 4 approbation maxims, and 6 symphaty maxims.
\end{abstract}

Keywords: Politeness principles; speech acts

\section{INTRODUCTION}

Speech acts are the part of pragmatic science which contains interpretations about an utterance that is uttered by speakers to their partners of speech. Speech acts can be interpreted as an individual symptom and to achieve a desired goal in speech, the speaker's language skills are needed to deal with a particular situation (Chaer, 2004). Speech acts generally can be divided into three, namely locutionary acts, illocutionary acts, and perlocutionary_ acts. Those three parts of speech act have differences in interpreting an utterance spoken by the speaker. Locutionary acts are the speech acts that contained utterance only limited to convey information to the partner of speech without any other intentions desired by the speaker. Illocutionary acts are the speech acts that contained utterances that have the implied meaning and purpose, so the partner of speech needs to interpret the intent of the utterances uttered by the speaker. Perlocutionary acts contain utterance that is uttered by speakers to their partners of speech that encourage the partner of speech to perform an action based on the utterance spoken by the speaker.

Illocutionary acts are the speech acts that contain utterances that have implicit meanings inside, so the partner of speech must be able to interpret the utterances uttered by speakers. Based on this concept, illocutionary acts can be categorized into 5, namely assertive, directive, commissive, expressive, and declarative categories (Leech, 1983). Classification of illocutionary acts can be used to analyze politeness principles contained in a speech act. The principle of politeness can be divided into six maxims in the form of tact maxim, 
generosity maxim, approbation maxim, modesity maxim, agreement maxim, and symphaty maxim. Each of these maxims has the concept of politeness in speaking. One form of the use of speech acts in language is the utterance contained in the advertisement. Thus, this article will discuss about speech acts on advertisements. The data that will be used in this research is in the form of moving adversitement, they are toothpaste adversitement that have been aired on television. The data were taken from youtube, they are about toothpaste advertisements for both toothpaste for children and adults that were aired in the period (2015-2018).

In supporting the research idea, several related studies have been collected to support the topic. All of the following studies have made a major contribution in conducting this research. Following are some studies on speech acts and politeness principles. First, research conducted by Umar (2016) entitled The Analysis of Speech Act of President Joko Widodo at APEC Forum analyzed illocutionary and perlocutionary functions found in a speech (Umar, 2016). Second, a research entitled Analisis Tindak Tutur Dalam Novel Ayat-Ayat Cinta Karya Habiburrahman El Shirazy, analyzing the types of speech acts and values contained in a novel (Gamgulu, 2015). Third, a research entitled Tindak Tutur Lokusi dan Perlokusi Dalam Dialog Film 5 CM Karya Rizal Mantovani, the research contributes through a clear explanation and understanding of the differences between locutionary and perlocutionary acts (Oktaviani, 2015). Fourth, research conducted by Hadi (Hadi, 2016) entitled Tuturan Orang tua dan Anak dalam Acara Supernanny Sebuah Kajian Tindak Tutur contributes by giving an explanation about the form of speech acts and functions in speech between children and parents. The last, the research conducted by Prasetya (Prasetya, 2017) entitled Tindak Tutur pada Iklan Produk Minuman Teh di Televisi dan Implikasinya dalam Pembelajaran Bahasa Indonesia di Sekolah Menengah Pertama contributed that by analyzing the forms of speech acts in an advertisement can be used as a topic of Indonesian language learning for Junior High School students.

\section{Speech Acts}

Speech acts are part of pragmatic studies. Speech acts as expressions expressed by the speaker to the listener to convey a specific purpose (Kridalaksana, 1982). Another opinion states that speech acts can be interpreted as an individual symptom and in order to achieve a desired purpose in speech, it is necessary to have the language skills mastered by the speaker to deal with a particular situation (Chaer, 2004). Thus, speech acts can be described as an utterance delivered by the speaker to his audience in a context and with a specific intention and purpose, both to convey information and to get a response from his partner of speech.

\section{Politeness Principles}

Politeness refers to two participants involved in a speech act in which speakers in a speech must consider politeness about what is permissible and what should not be said when delivering utterance (Leech, 1983). Thus, Leech divides the principle of speech into six parts, namely tact maxim, generosity maxim, approbation maxim, modesity maxim, agreement maxim, and symphaty maxim.

\section{METHOD}

The data in this research were taken from toothpaste advertisements that have been shown on television channels. The adversitement were taken from Youtube in the form of children's and adult's toothpaste advertisements in the period (2015-2018). The data collected are in the form of image footages and utterances contained in the adversitement. Data were analyzed using the speech act theory (Yule, 1996), category of illocutionary acts teory proposed and the politeness principle theory proposed (Leech, 1983).

\section{III.RESULT AND DISCUSSION}

\section{Type of Speech Acts}

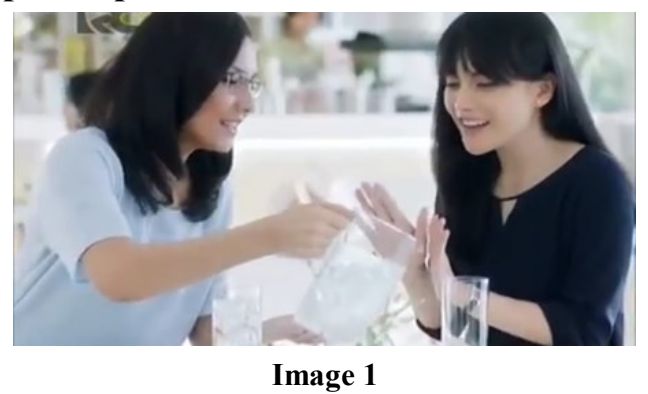

Speech Acts on Adult Toothpaste Adversitement on Youtube Period (2015-2018)

In this part of advertisement, the speaker and her partner of speech discuss about the sensitive teeth. When the partner of speech will pour ice into the speaker's glass, the speaker rejects it, and the following is his speech: "Enggak deh, gigiku sensitif, sudah pakai pasta gigiku sih, tapi khawatir ngilunya datang lagi" 
The partner of speech gives the response toward to the speaker's utterance: "Coba yang baru yuk"

In the utterance that is uttered by the speaker that "Enggak deh, gigiku sensitif, sudah pakai pasta gigiku sih, tapi khawatir ngilunya datang lagi", there is locutionary act that contain information that her teeth are sensitive to cold water stimulation. In addition, speakers also provided information that speakers also used her special toothpaste, but she is still worried that there would be a sense of pain if she consumed ice. In that utterance, there is illocutionary act especially assertives category which have implicit meaning of declaring and reporting. That utterance that is uttered could be interpreted as a stating expression that the speaker refused the cold water from her partner of speech which was indicated by the expression "Enggak deh" That utterance also contained assertive illocutionary acts that is intended to report something, it is indicated by utterances "gigiku sensitif, sudah pakai pasta gigiku sih, tapi khawatir ngilunya datang lagi" "That utterance is intended by the speakers to tell her partner of speech that she had used special toothpaste but she doubted that her toothpaste is not enough to protect her teeth from feeling aches when eating foods that can stimulate pain in the teeth.

The utterance that is uttered by the speaker also contains perlocutionary act that is showed by the effects arising based on that utterance, so that the partner of speech understand and give a response toward the utterance by inviting speakers to try using other toothpaste. That utterance shows that there is perlocutionary act signalled by response and action given by partner of speech on speech events such as in that part of advertisement, that is by saying "Coba yang baru yuk" with intention to invite the speaker to try the new toothpaste product.

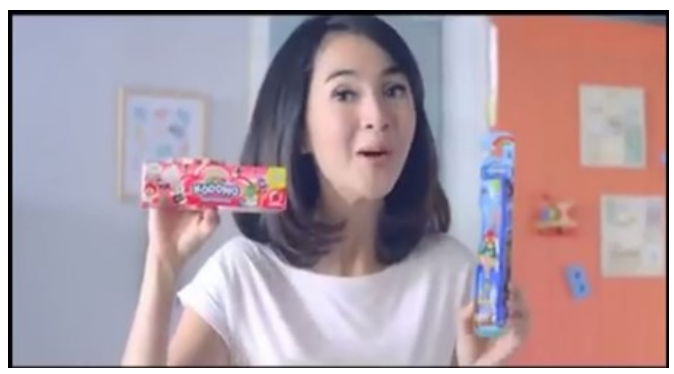

Image 2

Speech Acts on Children's Toothpaste Adversitement on Youtube Period (2015-2018)
In this part of advertisement there are utterances uttered by the speaker and the partner of speech. The utterance uttered by speaker is "Yuk sikat gigi dengan pasta gigi Kodomo baru" The partner of speech gives the response toward to the speaker's utterance, that is "Yeee rasa stroberi".

The utterance uttered by speaker in that advertisement image contains the locutionary act that contained information that Kodomo toothpaste had a new variant flavor, namely strawberry flavor. Illocutionary acts in that utterance can be categorized as direct illocutionary acts aimed at providing recommendations. Through utterance "Yuk sikat gigi dengan pasta gigi Kodomo baru", the speaker intends to recommend the partner of speech to use Kodomo toothpaste with the new variant flavor, that is strawberry flavor. That utterance that is uttered by the speaker also shows the perlocutionary act arrised by the partner of speech. That perlocutionary act is in the form of response from the partner of speech by saying "Yeee rasa stroberi". The response shows the expression of the partner of speech who feels happy with the new flavor variant of the toothpaste.

\section{Politeness Principles}

The Principle of Politeness in Toothpaste Adversitement on Youtube Period (2015-2018)

1) Tact Maxim

The principle of tact maxim is to make the other people get the the smallest possible losses and make them get the greatest possible profit. Tact maxim is found in the directive and commissive categories of illocutionary acts. Following is the tact maxim found in toothpaste adversitement on youtube for the period (20152018).

Utterance "Makanya pilih pasta gigi yang bener. Ganti! Ganti! Ganti ke Formula Strong!" (Formula Strong Toothpaste Ad Period 2015).

That utterance contains directive category illocutionary acts. That utterance is uttered by the speaker with the intention to give a message to the audience to choose the right toothpaste. The message intended by the speaker contains tact maxim that can make the smallest possible loss and make as much profit as possible that is for the audience to avoid losses due to not choosing the right toothpaste.

2) Approbation Maxim

Approbation maxim has the principle of criticizing other people as little as possible and 
praising as much as possible. This maxim found in illocutionary acts of expressive and assertive categories. Following is the approbation maxim found in toothpaste adversitement on youtube for the period (20152018).

Utterance "Sejak pakai Ciptadent Maxi Herbal, gusiku tidak bengkak lagi" (Ciptadent Toothpaste Ad Period 2015).

That utterance contained illocutionary acts that has the implicit meaning. Illocutionary acts in that utterance is the expressive category illocutionary acts which have the implicit intention to give praise. By utterance "Sejak pakai Ciptadent Maxi Herbal, gusiku tidak bengkak lagi", the speaker intends to give the praise toward to the Ciptadent Herbal toothpaste product, it is due to that product can protect the health of speaker's gum since speaker used the toothpaste, hers gum never swelling as when she used other toothpaste. The praise that is uttered by the speaker contains the approbation maxim by giving as many praises as possible to other people and in this case, praise is given as much as possible to Ciptadent Herbal toothpaste products which have been shown to provide comfort feeling to the speaker's gum.

\section{3) Symphaty Maxim}

Symphaty maxim is part of the principle of politeness that is done by reducing to the smallest possible sense of antipathy towards others and increasing as much sympathy as possible for others. Symphaty maxim is found in assertive category of illocutionary acts. Following is the symphaty maxim found in toothpaste adversitement on youtube for the period (2015-2018).

Utterance "Akibat gigi sensitif mereka tidak dapat menikmati kebersamaan bersama orang terdekat, saat rasa ngilu itu muncul akan terasa langsung nyuuuutt di gigi. Rasa ngilu terhadap gigi sensitif tidak dapat sembuh sendiri, dia akan datang kembali jika kita tidak menanganinya lebih lanjut" (Sensodyne Toothpaste Ad Period 2016).

In that utterance there is an illocutionary act of assertive category which has the implicit meaning. That implicit intention is to report and express opinions. By utterance "Akibat gigi sensitif mereka tidak dapat menikmati kebersamaan bersama orang terdekat, saat rasa ngilu itu muncul akan terasa langsung nyuuuutt di gigi. Rasa ngilu terhadap gigi sensitif tidak dapat sembuh sendiri, dia akan datang kembali jika kita tidak menanganinya lebih lanjut', the speaker intends to give the report to the audience that some people who feel pain in their teeth cannot enjoy the togetherness with their closest people because they focus on the pain in their teeth. That utterance is also intended to give the advice to the audience that if they are not taking care immediately toward that pain, the feeling of pain would be even worse. This utterance with the intention of providing a report and giving advice contains the symphaty maxim that shows as much sympathy as possible for others. The sympathy shown by the speakers in that advertisement is that speaker expresses the experience of some people who feel a sense of pain in their teeth unable to enjoy their togetherness with their families and speakers also express advice for the audiences who also feel pain in their teeth to immediately deal with the problem so as not to become getting worse.

\section{IV.CONCLUSION}

The research conducted shows that there are differences between locutionary and illocutionary acts found in adult and children's toothpaste adversitement on youtube period (2015-2018). The locutionary and illocutionary acts found in adult toothpaste advertisements show the utterances that contain information about the advantages of toothpaste to maintain dental health, while in children's toothpaste advertisements show the utterances that contain information about things that can attract the audience's especially children to interest that toothpaste due to the nonverbal elements in the toothpaste adversitement.

The illocutionary acts found in this data of research are illocutionary acts of assertive, directive, commissive, expressive, and declarative categories. The illocutionary acts found in toothpaste advertisements on youtube for the period (2015-2018) are 6 assertive utterances, 9 directive utterances, 6 commissive utterances, 6 expressive utterances, and 2 declarative utterances.

The politeness principles in this research can be analyzed through classification of illocutionary acts. The politeness principles found in this research are tact maxim, approbation maxim, and symphaty maxim. Politeness principles found in toothpaste advertisements on youtube period (2015-2018) are 15 tact maxims, 4 approbation maxims, and 6 symphaty maxim.

\section{REFERENCES}


Chaer, A. (2004). Linguistik Umum. Jakarta: Rineka Cipta.

Gamgulu, N. (2015). Analisis Tindak Tutur Dalam Novel Ayat-Ayat Cinta Karya Habiburrahman El Shirazy. Jurnal Elektronik Fakultas Sastra Universitas Sam Ratulangi, 3(2), 1-18.

Hadi, A. R. (2016). Tuturan Orang Tua dan Anak dalam Acara Supernanny: Sebuah Kajian Tindak Tutur. Universitas Udayana.

Kridalaksana, H. M. (1982). Kamus Linguistik. Jakarta: PT Gramedia.

Leech, G. (1983). Principle of Pragmatics. London and New York: Longman.

Oktaviani, S. (2015). Tindak Tutur Lokusi
danPerlokusi Dalam Dialog Film 5 CM Karya Rizal Mantovani. Electronic Theses and Dissertation. Universitas Muhammadiyah Surakarta. https:// doi.org/10.1145/3132847.3132886

Prasetya, R. A. (2017). Tindak Tutur pada Iklan Produk Makanan Cepat Saji di Televisi dan Implikasinya dalam Pembelajaran Bahasa Indonesia di Sekolah Menengah Pertama. Universitas Bandar Lampung.

Umar, T. F. (2016). The Analysis of Speech Act of President Joko Widodo at APEC Forum. Universitas Islam Negeri Alauddin Makassar.

Yule, G. (1996). Pragmatics. New York: Oxford University Press. 